\title{
Interactive effect of calcium and magnesium on growth of Schefflera arboricola cuttings
}

\author{
Bakht Baidar*, Gohar Ayub, Nadia Bostan, Fazal Rabi, Junaid Khan,
} Asif Ali and Imtiaz Ahmad

Department of Horticulture, The University of Agriculture, Peshawar.

*Corresponding author's email: baidarhort 777@yahoo.com

Citation

Bakht Baidar, Gohar Ayub, Nadia Bostan, Fazal Rabi, Junaid Khan, Asif Ali and Imtiaz Ahmad. Interactive effect of calcium and magnesium on growth of Schefflera arbolicola cuttings. Pure and Applied Biology. Vol. 4, Issue 4, 2015, pp 568-574. http://dx.doi.org/10.19045/bspab.2015.44016

Received: 09/08/2015

Revised: $16 / 112015$

Accepted: $25 / 11 / 2015$

\section{Abstract}

As calcium is required for shoot and root growth whereas magnesium is necessary for sugar production and dark green leaves but no research work concerning the "Interactive effect of Calcium and Magnesium on rooting and growth of Schefflera arboricola cuttings" is available in Pakistan, thus to check the desired effect an experiment was conducted at Ornamental Nursery Farm, Department of Horticulture, The University of Agriculture Peshawar. Calcium and magnesium each at $0,5,10,15$, and $20 \%$ were used both alone and in combination. Maximum number of leaves plant ${ }^{-1}(42.94)$, leaf area $\left(12.84 \mathrm{~cm}^{2}\right)$, sprout length $(18.21 \mathrm{~cm})$, sprout thickness $(0.65 \mathrm{~cm})$, and plant survival percentage $(89.27 \%)$ was caused by calcium alone at the rate of $20 \%$ caused whereas magnesium alone at the rate of $10 \%$ resulted in better number of leaves plant $^{-1}$ (39.69), average leaf area $\left(10.77 \mathrm{~cm}^{2}\right)$, sprout length $(15.56 \mathrm{~cm})$, survival percentage $(83.33 \%)$ and sprout thickness $(0.51 \mathrm{~cm})$. Earliest sprouting and highest sprouting percentage were observed in cutting treated with no calcium and magnesium. Cutting treated with calcium and magnesium at the rate of $20 \%$ and $10 \%$ respectively produced highest number of leaves plant $^{-1}(46.10)$, leaf area $\left(13.90 \mathrm{~cm}^{2}\right)$, sprout length $(19.03 \mathrm{~cm})$, sprout thickness $(0.70 \mathrm{~cm})$ and survival percentage (96.67\%). Hence 20\% calcium and 10\% magnesium each alone and in combination respectively are recommended for the good quality plant growth of Schefflera arboricola propagation through cuttings.

Key words: Sprout; Survival; Leaf; Calcium; Magnesium.

\section{Introduction}

Schefflera arboricola is an ornamental evergreen shrub belongs to family Araliaceae, native to China. It is commonly known as "Dwarf umbrella tree". It is foliage plant, normally growing three to four meter in height. Several cultivars have been developed for variation in leaf color and configurations, frequently variegated with centers or creamy white to yellow edges. [1]. Schefflera arboricola is used, as landscape plants, as foliage plant (specimen plant), as cut flower, as filler and can be grown in containers as an indoor plant. Besides, it can also be used as medicinal plant. Being an important ornamental foliage 
plant, it has great potential in the market. Hence we need to propagate it in enormous amount to satisfy the market demand. Schefflera is generally propagated by two methods i.e. sexual and asexual propagation. Asexual propagation includes micro propagation, air layering and cutting. Cutting propagation is often the preferred method for plant propagation because it is the easiest and least expensive way to produce a clone of a particular parent plant while other methods i.e. grafting, layering and micro propagation are more difficult as these methods need skillful labours and more expenses. Shefflera arboricola is hard to root by propagation through cuttings which means, it may be auxotrophic in nature. Different rooting hormones are using for initiating roots in cuttings but they are expensive enough that nurserymen cannot use it on commercial scale. Besides hormones, calcium and magnesium also play a pivotal role in root initiation. Magnesium is important nutrient for being its role in root formation, chlorophyll and photosynthesis [2]. Calcium is an important element for root functioning and development [3]. Both these nutrients are comparatively cheaper than hormones. Keeping in view the importance of nutrients for plant growth this experiment was planned to study the optimum level of calcium and magnesium as well as their interaction for better plant growth.

\section{Materials and Methods}

An investigation to find out the "Interactive effect of calcium and magnesium on growth of Schefflera arboricola cuttings" was conducted at Ornamental Nursery farm, Department of Horticulture, The University of Agriculture Peshawar. The experiment was design as randomized complete block design (RCBD) with two factors factorial arrangement and treatments were replicated three times. The plastic bags ( $5 \times 7$ inches) were filled with farm yard manure, silt and sand at 1:1:1 and were settled according to the experimental design at the ornamental nursery. About 3 inches long cuttings containing at least three buds were used in the experiment. The cuttings were treated with calcium and magnesium each at the rate of $0 \%, 5 \%, 10 \%, 15 \%$ and $20 \%$ alone and in combination. Lightly irrigation was carried out just before planting the cuttings and all the cultural operations like weeding, irrigation were practiced at appropriate time and regular interval throughout the experiment. The cuttings were planted on $28^{\text {th }}$ May and were uprooted on $29^{\text {th }}$ November.

Data collected on days to sprouting, survival percentage, sprouting percentage, sprout length $(\mathrm{cm})$, sprout thickness plant ${ }^{-1}(\mathrm{~cm})$, number of leaves plant ${ }^{-1}$ and leaf area $\left(\mathrm{cm}^{2}\right)$ was statistically analyzed according to the technique related to randomize complete block design (RCBD) with two factors experiment through using a statistical package Statistics.

\section{Results and Discussion}

\section{Days to sprouting:}

Data regarding days to sprouting is presented in Table 1. According to the analysis of variance, days to sprouting were affected significantly by calcium, magnesium and their interaction. Regarding calcium treatments, earliest sprouting (38.3 days) was observed in cuttings treated with no calcium whereas calcium at the rate of $20 \%$ showed late sprouting (43.91 days). The mean data regarding magnesium revealed that earliest sprouting (40.1 days) was observed in cuttings treated with no magnesium followed by magnesium at the rate of $5 \%$ (41.45 days) whereas late sprouting (43 days) was observed in cuttings treated with $20 \%$ magnesium. As interaction is concern the cuttings treated with magnesium and calcium each at the rate of $0 \%$ caused earlier sprouting (35.1 days) whereas magnesium and calcium both at the rate of $20 \%$ resulted in late sprouting (45.5 
days). The late sprouting in calcium and magnesium treated cuttings might be due to the food and energy consumption in activation of enzymes at the spot of application so low food and energy was available to the upper the part to be sprouted, besides the cutting treated with no calcium and magnesium consume the all energy and food in initiation of early sprouting..

Table 1. Days to sprouting of Schefflera arboricola, as treated with different levels of calcium and magnesium.

\begin{tabular}{l|lllll|l}
\hline \multirow{2}{*}{ Magnesium (\%) } & \multicolumn{5}{|c|}{ Calcium (\%) } & \multirow{2}{*}{ Mean } \\
\cline { 2 - 6 } & 0 & 5 & 10 & 15 & 20 & 40.16 \\
0 & 35.17 & 38.33 & 41.2 & 43.1 & 43 & 41.45 \\
5 & 36.8 & 40.33 & 42.83 & 43.97 & 43.33 & 41.96 \\
10 & 37.73 & 41.77 & 42.73 & 44.3 & 43.27 & 42.71 \\
15 & 38.67 & 41.93 & 44.07 & 44.5 & 44.4 & 43.83 \\
20 & 41.83 & 43.63 & 43.73 & 44.4 & 45.53 & \\
\hline Mean & 38.04 & 41.20 & 42.91 & 44.05 & 43.91 & \\
\hline
\end{tabular}

$\mathrm{LSD}$ value for calcium $=0.86, \quad \mathrm{LSD}$ value for magnesium $=0.86, \mathrm{LSD}$ for Calcium $\mathrm{x}$ magnesium $=1.93$

Plant Survival (\%).

As per data in Table 2 the analysis of variance showed that calcium and magnesium had significant while their interaction had non-significant effect on plant survival percentage. Data regarding the calcium showed a significant variation among different levels of calcium in which highest survival percentage $(89.27 \%)$ was noted in cuttings treated with calcium at the rate of $20 \%$ whereas lowest survival percentage $(69.67 \%)$ was observed in cutting treated with no calcium. According to the mean values pertaining magnesium, highest survival percentage $(83.33 \%)$ was noted in cutting treated with magnesium at the rate of $10 \%$ while lowest survival percentage $(72.80 \%)$ was recorded in cutting treated with no magnesium. The highest survival percentage might be due to the calcium and magnesium application with the cuttings as these chemicals enhancing the cell division, root growth and photosynthesis respectively. Once strong root system is developed by calcium, it will absorb more nutrients from the soil and magnesium is involved in chlorophyll formation so its application will promote the photosynthetic tissues so more food will be prepared by the plants, ultimately have high survival.

Table 2. Survival (\%) of Schefflera arboricola, as treated with different levels of calcium and magnesium.

\begin{tabular}{l|lllll|l}
\hline \multirow{2}{*}{ Magnesium (\%) } & \multicolumn{5}{|c|}{ Calcium (\%) } & \multirow{2}{*}{ Means } \\
\cline { 2 - 6 } & 0 & 5 & 10 & 15 & 20 & \\
\hline 0 & 65.00 & 68.00 & 67.67 & 79.67 & 83.67 & 72.80 \\
5 & 70.33 & 73.00 & 78.33 & 78.33 & 83.67 & 76.73 \\
10 & 69.67 & 81.00 & 81.00 & 88.33 & 96.67 & 83.33 \\
15 & 67.33 & 76.00 & 76.00 & 80.00 & 89.33 & 77.73 \\
20 & 76.00 & 74.17 & 77.67 & 84.67 & 93.00 & 81.10 \\
\hline Means & 69.67 & 74.43 & 76.13 & 82.20 & 89.27 & \\
\hline
\end{tabular}

LSD value for calcium $=3.28$

LSD value for magnesium $=3.28$ 


\section{Sprouting percentage:}

Mean values pertaining to sprouting percentage are given in Table-3. The analysis of variance showed a significance variation of calcium and magnesium on sprouting percentage while the effect of interaction between calcium and magnesium was found non-significant. Highest sprouting percentage $(75.13 \%)$ was observed in cuttings treated with no calcium followed by the cuttings treated with $5 \%$ calcium (69.07\%), whereas the lowest sprouting percentage (57.67\%) was noted in cuttings treated with calcium at the rate of 20\%. The means documented for magnesium indicate that highest sprouting percentage $(68.73 \%)$ was recorded in cuttings treated with no magnesium followed by the cutting treated with magnesium at the rate of $5 \%(67.03 \%)$, whereas the lowest sprouting percentage $(62.13 \%)$ was noted in cuttings treated with $5 \%$ magnesium. The reason for highest sprouting percentage at control treatments of calcium and magnesium might be due to the availability of all the store food only for the sprouting process whereas for root initiation no energy was used hence it survival percentage was very low as compare to calcium and magnesium treated cuttings.

Table 3. Sprouting percentage of Schefflera arboricola, as treated with different levels of calcium and magnesium.

\begin{tabular}{l|lllll|l}
\hline \multirow{2}{*}{ Magnesium (\%) } & \multicolumn{5}{|c|}{ Calcium (\%) } & \multirow{2}{*}{ Means } \\
\cline { 2 - 6 } & 0 & 5 & 10 & 15 & 20 & \\
\hline 0 & 84.67 & 73.33 & 66.00 & 60.6 & 59.00 & 68.73 \\
5 & 78.00 & 69.00 & 66.00 & 62.5 & 59.67 & 67.03 \\
10 & 72.33 & 68.33 & 64.33 & 61.0 & 60.33 & 65.27 \\
15 & 72.00 & 68.00 & 67.67 & 59.0 & 55.33 & 64.40 \\
20 & 68.67 & 66.67 & 63.33 & 58.0 & 54.00 & 62.13 \\
\hline Means & 75.13 & 69.07 & 65.47 & 60.2 & 57.67 & \\
\hline
\end{tabular}

LSD value for calcium $=2.98, \quad L S D$ value for magnesium $=2.98$

\section{Sprout length (cm)}

The data recorded for sprout length is presented in Table-4. The analysis of variance showed that calcium and magnesium significantly affect while their interaction non-significantly affect sprout length $(\mathrm{cm})$ of Schefflera. Perusal of the data regarding calcium concluded that maximum sprout length $(18.21 \mathrm{~cm})$ was noted in cuttings treated with calcium at the rate of $20 \%$, which is at par with those treated with $15 \%(16.77 \mathrm{~cm})$, while minimum sprout length $(10.81 \mathrm{~cm})$ was recorded in cuttings treated with no calcium. Data regarding magnesium concluded that maximum sprout length $(15.56 \mathrm{~cm})$ was observed in cuttings treated with magnesium at the rate of $10 \%$, followed by cuttings treated with $15 \%$ $(15.32 \mathrm{~cm})$ whereas minimum sprout length $(14.15 \mathrm{~cm})$ was noted in cuttings treated with no magnesium. Maximum sprout length at high calcium level might be due to the fact that calcium is involved in metabolic activities and cell division [4]. These results are in accordance with the findings of [5] who reported that Calcium and Magnesium significantly increased celery above-ground fresh weight, total dry biomass and leaf area compared to low and high levels. 
Table 4. Sprout length $(\mathrm{cm})$ of Schefflera arboricola, treated with different levels of calcium and magnesium.

\begin{tabular}{l|lllll|l}
\hline \multirow{2}{*}{ Magnesium (\%) } & \multicolumn{5}{|c|}{ Calcium (\%) } & \multirow{2}{*}{ Mean } \\
\cline { 2 - 6 } & 0 & 5 & 10 & 15 & 20 & \\
\hline 0 & 10.4 & 11.83 & 14.8 & 16.2 & 17.53 & 14.15 \\
5 & 10.57 & 12.33 & 15.1 & 16.43 & 18.13 & 14.51 \\
10 & 11.27 & 14.33 & 16 & 17.17 & 19.03 & 15.56 \\
15 & 11.03 & 13.7 & 15.87 & 17.17 & 18.83 & 15.32 \\
20 & 10.77 & 12.9 & 15.4 & 16.87 & 17.5 & 14.69 \\
\hline Mean & 10.81 & 13.02 & 15.43 & 16.77 & 18.21 & \\
\hline
\end{tabular}

LSD value for calcium $=0.33, \quad$ LSD value for magnesium $=0.33$

\section{Sprout thickness (cm)}

Mean values pertaining to sprout thickness are presented in Table 5. Analysis of variance showed that sprout thickness is significantly affected by calcium and magnesium whereas non-significantly affected by their interaction. Data regarding calcium showed that maximum sprouting thickness $(0.65 \mathrm{~cm})$ was observed in cuttings treated with calcium at the rate of $20 \%$, followed by cuttings treated with $15 \%$ calcium $(0.54 \mathrm{~cm})$, whereas minimum sprout thickness $(0.30 \mathrm{~cm})$ was noted in cuttings treated with no calcium. The mean data for magnesium showed that maximum sprouting thickness $(0.51 \mathrm{~cm})$ was observed in the cuttings treated with magnesium at the rate of $10 \%$, followed by cuttings treated with $15 \%$ magnesium $(0.49 \mathrm{~cm})$ whereas minimum thickness $(0.42 \mathrm{~cm})$ was noted in cuttings treated with no magnesium. Thickest stem might be due to calcium and magnesium treatment, as calcium improves the cell division and cell enlargement while magnesium activates many enzyme needed for plant growth. These finding are in conformity with the finding of [6] who reported that thickest stem was found in plants treated with calcium.

Table 5. Sprouting thickness $(\mathrm{cm})$ of Schefflera arboricola, as treated with different levels of calcium and magnesium.

\begin{tabular}{l|lllll|l}
\hline \multirow{2}{*}{ Magnesium (\%) } & \multicolumn{7}{|c|}{ Calcium (\%) } & \multirow{2}{*}{ Mean } \\
\cline { 2 - 6 } & 0 & 5 & 10 & 15 & 20 & \\
\hline 0 & 0.26 & 0.32 & 0.39 & 0.51 & 0.6 & 0.42 \\
5 & 0.26 & 0.34 & 0.4 & 0.51 & 0.63 & 0.43 \\
10 & 0.37 & 0.4 & 0.49 & 0.59 & 0.7 & 0.51 \\
15 & 0.32 & 0.45 & 0.46 & 0.56 & 0.68 & 0.49 \\
20 & 0.29 & 0.37 & 0.43 & 0.54 & 0.66 & 0.46 \\
\hline Mean & 0.30 & 0.38 & 0.43 & 0.54 & 0.65 & \\
\hline
\end{tabular}

LSD value for calcium $=0.02, \quad$ LSD value for magnesium $=0.02$.

Number of leaves plant ${ }^{-1}$ :

Data regarding number of leaves plant $^{-1}$ is presented in Table-6. Analysis of variance showed that number of leaves per plant ${ }^{-1}$ is significantly affected by calcium and magnesium while non-significantly by their interaction. Data regarding calcium indicated that more number of leaves (42.94) plant $^{-1}$ was found in cuttings treated with calcium at the rate of $20 \%$ which is at 
par with those treated with $15 \%$ calcium (39.53), whereas less numbers of leaves (28.67) plant $^{-1}$ were produced by those treated with no calcium. The data for magnesium showed that highest number of leaves (39.69) plant $^{-1}$ was noted in cuttings treated with $10 \%$ magnesium which significantly varies from the rest of the treatments, followed by $15 \%$ magnesium (37.0) leaves plant ${ }^{-1}$ while minimum number of leaves (32.07) plant $^{-1}$ was produced by cuttings treated at $0 \%$ magnesium.
Maximum number of leaves might be due to calcium and magnesium application, as calcium increase the roots number, absorbing more nutrients and magnesium enhance the photosynthesis rate as it improves the chlorophyll contents of plants and activates enzymes essential for plant growth. These finding are in agreement with the findings of [6] who reported that calcium improved number of leaves when Ficus benjamina plants were treated with calcium.

Table 6. Number of leaves plant ${ }^{-1}$ of Schefflera arboricola, as treated with different levels of calcium and magnesium.

\begin{tabular}{l|lllll|l}
\hline \multirow{2}{*}{ Magnesium (\%) } & \multicolumn{5}{|c|}{ Calcium (\%) } & \multirow{2}{*}{ Means } \\
\cline { 2 - 6 } & 0 & 5 & 10 & 15 & 20 & \\
\hline 0 & 25.33 & 28.33 & 32.33 & 35.33 & 39 & 32.07 \\
5 & 27 & 30 & 34 & 39.33 & 41.5 & 34.37 \\
10 & 34.67 & 35 & 39.33 & 43.33 & 46.1 & 39.69 \\
15 & 29 & 33 & 36.67 & 41.33 & 45 & 37.00 \\
20 & 27.33 & 31.33 & 36.33 & 38.33 & 43.1 & 35.29 \\
\hline Mean & 28.67 & 31.53 & 35.73 & 39.53 & 42.94 & \\
\hline
\end{tabular}

LSD value for calcium $=1.09, \quad$ LSD value for magnesium $=1.09$

Leaf area $\left(\mathrm{cm}^{2}\right)$ :

Mean values concerning leaf area is presented in table 7. Analysis of variance revealed that leaf area is affected significantly by calcium, magnesium and their interaction. Data regarding calcium showed that maximum leaf area $\left(12.84 \mathrm{~cm}^{2}\right)$ was noted in cuttings treated with $20 \%$ calcium, followed by $15 \%$ calcium $(11.41$ $\mathrm{cm}^{2}$ ), whereas calcium at the rate $0 \%$ caused lowest leaf area $\left(7.03 \mathrm{~cm}^{2}\right)$. the data for magnesium showed that maximum leaf area $\left(10.77 \mathrm{~cm}^{2}\right)$ was noted in cuttings treated with $10 \%$ magnesium followed by $15 \%$ magnesium $\left(9.73 \mathrm{~cm}^{2}\right)$, whereas minimum leaf area $\left(8.17 \mathrm{~cm}^{2}\right)$ was noted in cuttings treated with no magnesium. The data documented for interaction revealed that the cuttings treated with magnesium and calcium at the rate of 20 and $10 \%$ produced maximum leaf area $\left(13.90 \mathrm{~cm}^{2}\right)$ whereas calcium and magnesium both at the rate of $0 \%$ each resulted in lowest leaf area (5.10 $\mathrm{cm}^{2}$ ). The increase in leaf area might be due to calcium and magnesium application as calcium activates specific enzymes, enhancing the efficiency of protein pump, improved the roots number, which ultimately absorb more nutrients, utilized by the plant for the production of large healthy leaves whereas magnesium helps in chlorophyll pigment production, as it is important component of the chlorophyll molecule, aids in more Photosynth ate production and resulting in good healthy leaves. These finding are closely related to the findings of with [7] who reported that Calcium deficiencies results a decline in reduces leaf size and the growth of meristematic tissues. 
Table 7. Leaf area $\left(\mathrm{cm}^{2}\right)$ of Schefflera arboricola, as treated with different levels of calcium and magnesium.

\begin{tabular}{l|lllll|l}
\hline \multirow{2}{*}{ Magnesium (\%) } & \multicolumn{5}{|c|}{ Calcium (\%) } & \multirow{2}{*}{ Mean } \\
\cline { 2 - 6 } & 0 & 5 & 10 & 15 & 20 & \\
\hline 0 & 5.10 & 5.27 & 8.33 & 10.23 & 11.93 & 8.17 \\
5 & 5.33 & 5.93 & 8.70 & 10.77 & 12.33 & 8.61 \\
10 & 8.10 & 9.20 & 10.10 & 12.57 & 13.90 & 10.7 \\
15 & 5.90 & 8.00 & 9.50 & 11.97 & 13.30 & 9.73 \\
20 & 5.60 & 6.70 & 9.13 & 11.50 & 12.73 & 9.13 \\
\hline Mean & 6.01 & 7.02 & 9.15 & 11.41 & 12.84 & \\
\hline
\end{tabular}

LSD value for calcium $=0.31, \mathrm{LSD}$ value for magnesium $=0.31, \mathrm{LSD}$ for Calcium $\mathrm{x}$ magnesium $=0.69$

\section{Conclusion and Recommendation}

The above stated experiment it is concluded that cutting treated with $20 \%$ calcium and $10 \%$ magnesium showed best results regarding number of leaves plant $^{-1}$, plant height, leaf area, sprout thickness, root length, number of roots, plant survival percentage and root weight. Earlier sprouting and highest sprouting percentage was recorded in cuttings treated with no calcium and magnesium. Hence on the basis of these conclusions it is recommended that Calcium and Magnesium at the rate of $20 \%$ and $10 \%$ respectively, are recommended for the production of quality plants of Schefflera arboricola propagated through cuttings.

\section{Authors' contributions}

Conceived and designed the experiments: $G$ Ayub, Performed the experiments: B Baidar, Analyzed the data: F Rabi \& J Khan, Contributed reagents/materials/analysis tools: A Ali \& I Ahmad, Wrote the paper: N Bostan.

\section{References}

1. Edward F (1999). Plant Propagation Principles and Practice. Enviromental Horticulture Department cooperative
2. Extension Service Institute of food and Agricultural Sciences University Florida. USA.

3. Chakmak I and Yazici A M (2010). Magnesium. A forgotten element in crop production. better Crops. 94 (2): 23-24.

4. Zekri M, Obreza T A (2009). Plants nutrients for citrus trees. Uni. of Florida, Ext. report.

5. Hepler S and Wayne M (1985). Plant development. Annual review of plant physiology 36: 394-435.

6. Li Y, Wang T, Li J, Ao Y (2010). Effect of phosphorus on celery growth and nutrient uptake under different calcium and magnesium levels in substrate culture. Hort. Sci. (Prague), 37: 99-108.

7. Attia F A, Abdou M A and. Mohamed M A (2004). The effect of calcium super phosphate on ficus bejumana. J. Agric. Sci. 29: 787-797.

8. Hao X \& Papadopoulos A P (2003). Effects of calcium and magnesium on growth, fruit yield and quality in a fall greenhouse tomato crop grown on Rockwool. J. Plant Sci. I, 83, 903-912. 